\title{
Dangerous pseudo-academic liaisons
}

\author{
Guillermo J. Ruiz-Argüelles* \\ Centro de Hematología y Medicina Interna de Puebla, Clínica Ruiz, Puebla, Mexico
}

"Dangerous liaisons" is a 1988 American period romantic drama film directed by Stephen Frears from a screenplay by Christopher Hampton, based on his play "Les Liaisons dangereuses," which was itself adapted from the $18^{\text {th }}$ century French novel of the same name by Pierre Choderlos de Laclos. A liaison is an instance or a means of communication between different groups or units of an organization. In his novel, Pierre-Ambroise-Francois Choderlos de Laclos (1741-1803) referred to sentimental liaisons in the French aristocracy.

In the practice of medicine, there are other liaisons which, along time, I have identified as "dangerous pseudo-academic liaisons." These liaisons have been mentioned in several ways and refer to the relationships between doctors and the medical industry ${ }^{1-5}$, itaest, the way doctors can be influenced by the medical industry. One of its consequences is the emergence of a new breed of persons conveying teachings to others: professionals trained by the pharmaceutical companies, whose activity is oriented to convince their peers of the usefulness and advantages of certain drugs or medical procedures, sometimes unnecessary. These persons have been called key opinion leaders $(\mathrm{KOLs})^{6,7}$, and some of them are trained by the drug companies in specific meetings such as "Advisory Boards," "Master Classes," "Speaker Training Courses," or "Preceptorships," to deliver "lectures" employing material provided by the companies themselves. Very frequently, these persons do not have vast experience with the use of the drug they are trained to promote; rarely are teachers or professors and seldom are academicians nor academics, this being the reason for qualifying their lectures and their liaisons as "pseudo-academic." The pharmaceutical industry, in its marketing efforts, often turns to KOLs to disseminate scientific information. Partly due to the use of KOLs, some companies with well-defined and narrow interests have inordinate influence over how medical knowledge is produced, circulated, and consumed. David Steensma ${ }^{7}$ has stated that opinions are a nebulous area in which to be a leader; it is much better to be recognized for being an expert in scientific discovery, for the development of new effective therapies, or for something else tangible and useful such as publications. Moreover, he quotes Clint Eastwood in the "Dirty Harry" film, "Opinions are like $a^{\star *}$ holes- everyone has one........" . KOLs paid lecturers and paid speakers seem to move confidently within the platform of "dangerous pseudo-academic liaisons."

I have always thought that the alarming rise in the cost of hematological medical treatments stems from several reasons, one of them being these "dangerous pseudo-academic liaisons." In addition to being paid, the trained lecturers or speakers are offered luxurious trips, foods, drinks, and lodging which are paid, indirectly, by the patients - or they payers - consuming the promoted drugs. With these ideas in mind, I have just finished the analysis of patients with two hematological malignancies which in the past years have been the focus of the development of novel, very expensive drugs: multiple myeloma and chronic lymphocytic

\section{Correspondence:}

*Guillermo J. Ruiz-Argüelles

E-mail: gruiz1@ clinicaruiz.com
Available online: $17-03-2020$

Date of acceptance: $14-11-2019$ DOI: 10.24875/RMU.M20000037
Medicina Universitaria. 2020;22(1):1-2 www.medicinauniversitaria.org (http://creativecommons.org/licenses/by-nc-nd/4.0/) 
leukemia ${ }^{8,9}$. In my personal experience of 35 years of treating such patients, and in studies conducted in the era of novel drugs, we have found that employing simplified approaches in the treatment of patients with either multiple myeloma (108 patients) or chronic lymphocytic leukemia (98 patients). Furthermore, taking advantage of improved supportive care measures, acceptable results are obtained even if all of the new drugs are not routinely employed.

Interestingly, at least half a dozen of these patients were offered treatment with expensive novel drugs, when, in fact, no treatment was necessary nor indicated. These observations may be critical in developing countries, where the cost of the drugs will continue to be a significant factor in choosing therapies ${ }^{8-10}$. These data also support previous observations on the indiscriminate and unnecessary use of novel expensive drugs, which sometimes stem from influences of drug companies - dangerous pseudo-academic liaisons - rather than from genuine intents of improving the care of patients ${ }^{10}$. It seems that these dangerous liaisons are responsible, in part, for the alarming rise in the cost of medical treatments ${ }^{5}$. Something seems to be necessary to control these actions which both increase the revenues of the pharmaceutical companies and damage the well-being of the patients contributing to their financial toxicity; making these liaisons evident could be an initial step in the control of this situation.

\section{References}

1. Ruiz-Argüelles GJ. El producto interno bruto no apoya al producto interno inteligente del país. Med Univ. 2009;11:147-8.

2. Ruiz-Argüelles GJ. Sobre las lentejas, los profesionales de la salud y la industria farmacéutica. Narrativa médica en los 150 años de la academia nacional de medicina. 2014;1:225-8.

3. Ruiz-Argüelles GJ. Reflexiones sobre las relaciones entre médicos e industria farmacéutica. Rev Invest Clín Méx. 1997;49:79-80.

4. Celis MÁ, Halabe J, Arrieta O, Burgos R, Campillo C, De la Llata M, et al. Conflictos de intereses en medicina. Recomendaciones del CETREMI. Gac Med Mex. 2019;155:563-4.

5. Ruiz-Argüelles GJ, Steensma DP. Staunching the rising costs of haematological health care. Lancet Haematol. 2016;3:e455.

6. Ruiz-Argüelles GJ. A new breed in the teaching of medicine: paid lecturers, trainers or speakers. Acta Haematol. 2016;135:191-2.

7. Steensma DP. Key opinion leaders. J Clin Oncol. 2015;33:3213-4

8. Murrieta-Alvarez I, Steensma DP, Olivares-Gazca JC, et al. Treatment of persons with multiple myeloma in underprivileged circumstances: real world data of a study in a single institution. Blood. 2019;134:5707.

9. Cruz-Mora A, Murrieta-Alvarez I, Olivares-Gazca JC, León-Peña A, Cantero-Fortiz Y, García-Navarrete I, et al. Circa half of the patients with chronic lymphocytic leukemia in México do not need treatment: a 35-year, single institution experience. Submitted.

10. Ruiz-Argüelles GJ. Factors involved in the selection of treatment in patients with hematological malignancies. Acta Haematol. 2019;141:54. 